\title{
Current Dynamics of Hydric Erosion in the Kingouari, Mfilou and Djoué Watersheds in the Southwestern Part of Brazzaville City (Congo)
}

\author{
Jean de Dieu Nzila ${ }^{1,2, *}$, Noel Watha-Ndoudy ${ }^{2,3}$, Delestras Kaya-Mabiala ${ }^{1}$, \\ Pierre Mboungou-Nsompi ${ }^{1}$, Dieudonne Louembe ${ }^{2,4}$, Victor Kimpouni ${ }^{1,2}$, \\ Marie Joseph Samba Kimbata ${ }^{4}$ \\ ${ }^{1}$ Natural Sciences Department, Higher College of Teacher Training (ENS), Marien Ngouabi University, Brazzaville, Republic of Congo \\ ${ }^{2}$ National Forest Research Institute (IRF), Brazzaville, Republic of Congo \\ ${ }^{3}$ Geology Department, Sciences and Technics Faculty, (FST), Marien Ngouabi University, Brazzaville, Republic of Congo \\ ${ }^{4}$ Geography Department, Faculty of Literature, Arts and Humanities (FLASH), Marien Ngouabi University, Brazzaville, Republic of Congo
}

Email address:

jddnzila@yahoo.fr(J.de D. Nzila)

${ }^{*}$ Corresponding author

\section{To cite this article:}

Jean de Dieu Nzila, Noel Watha-Ndoudy, Delestras Kaya-Mabiala, Pierre Mboungou-Nsompi, Dieudonne Louembe, Victor Kimpouni, Marie Joseph Samba Kimbata. Current Dynamics of Hydric Erosion in the Kingouari, Mfilou and Djoué Watersheds in the Southwestern Part of Brazzaville City (Congo). Earth Sciences. Vol. 9, No. 5, 2020, pp. 201-209. doi: 10.11648/j.earth.20200905.16

Received: August 26, 2020; Accepted: September 15, 2020; Published: October 12, 2020

\begin{abstract}
The objective of this study is to quantify soil losses in the Kinsoundi 16A district, located in the Kingouari, Mfilou and Djoué watersheds. The aim is to highlight the current dynamic of water erosion in this southwestern part of Brazzaville's urban area and to evaluate the effectiveness of the control measures used. The methodological approach adopted was based on: (i) the measurement of the evolution of the soil surface, using profilometers placed on the 12 main roads in the district where 68 measurement points have been installed, (ii) the three-dimensional measurement (volume) of 22 ravines and gullies that incise the district, (iii) the measurement of slopes along arteries using a clinometer, (iv) the inventory of facilities used to control soil erosion, (v) interviews with populations to understand the history of the phenomenon and the control methods used. The soil losses by surface stripping, measured on 12 roads from 2007 to 2010 , are 78.1 t/ha. A destruction of 4.7 ha of land, or $2 \%$ of the Kinsoundi $16 \mathrm{~A}$ territory and $94,247 \mathrm{t} / \mathrm{ha}$ of land, was removed from these watersheds in 20 years by the 22 ravines. The aggressive nature of this dynamic is explained by the combination of the following natural and anthropogenic factors: frequent rains ( $\geq 15$ days/month) very erosive with a Rusa index of 287 to 866 points, sandy soils with more than $90 \%$, without cohesion and fragile, densification of the habitat on the ground ( 2 houses on average per plot of 400 $\mathrm{m} 2$ ), resulting in increased waterproofing of surfaces and responsible for the current erosive runoff, the absence of channels to canalize and control runoff, hence roads transformed into storm water collectors. The control measures used by the populations are inadequate and therefore not very effective (bags of soil that can be degraded in three months, used tires, solid waste dumped at the head of the ravines). Those financed by the State are expensive gabions but of limited effectiveness around the treated ravine. It is therefore imperative to treat the entire district as a risk watershed, by strengthening its vulnerable sectors and by building and developing a coherent system to control rainwater runoff. These curative measures must be underpinned by preventive actions that are more effective and less expensive.
\end{abstract}

Keywords: Brazzaville, Urban Space, Water Erosion, Gully, Profilometer

\section{Introduction}

Like many African cities, Brazzaville, the capital city of the Republic of Congo, is experiencing a strong demographic expansion that has the following consequences: (i) soil stripping by destroying vegetation, (ii) disruption of the 
water cycle by altering flows and channels, and (iii) land degradation by gullying and surface stripping associated with water erosion. Water erosion, particularly gullying erosion, has become catastrophic in Brazzaville's urban space in last years. These erosions have caused a series of damages and disasters such as: destruction of many houses, equipment and urban infrastructures, deaths of people swept away by the runoff, land degradation of affected neighborhoods, inaccessibility in some enclaved neighborhoods due to the destruction of roads, destruction of gorged cemeteries... [1].

This is a serious crisis that call urgent solutions that require first the knowledge of the dynamic of this erosion, and then analysis of the impacts of the anti-erosion control work carried out.

Studies carried out since 1978 on the main urban sites of Congo have attempted to qualitatively identify this dynamic and its impacts [1-3]. Studies on the quantification of erosive dynamics were initiated in Brazzaville in the Mfilou and
Djoué river basins from 2004 onwards [4-7].

The main objective of this study is to characterize the dynamics that drive catastrophic erosions in the urban space of Brazzaville, through the case of the Massina and Kinsoundi 16A districts, located in the Mfilou, Kingouari and Djoué catchments.

More specifically, it is about to:

1) characterize the vulnerability of the urban environment to water erosion risks;

2) show how the transformation of the urban site by the habitat, without adequate development, has made the rains and the flows they generate very erosive;

3) quantify the soil losses caused by this erosion to better assess its importance;

4) evaluate the impact of the developments carried out to control gullying erosion on the environment;

5) suggest some solutions that could control, if not mitigate, these erosion risks.

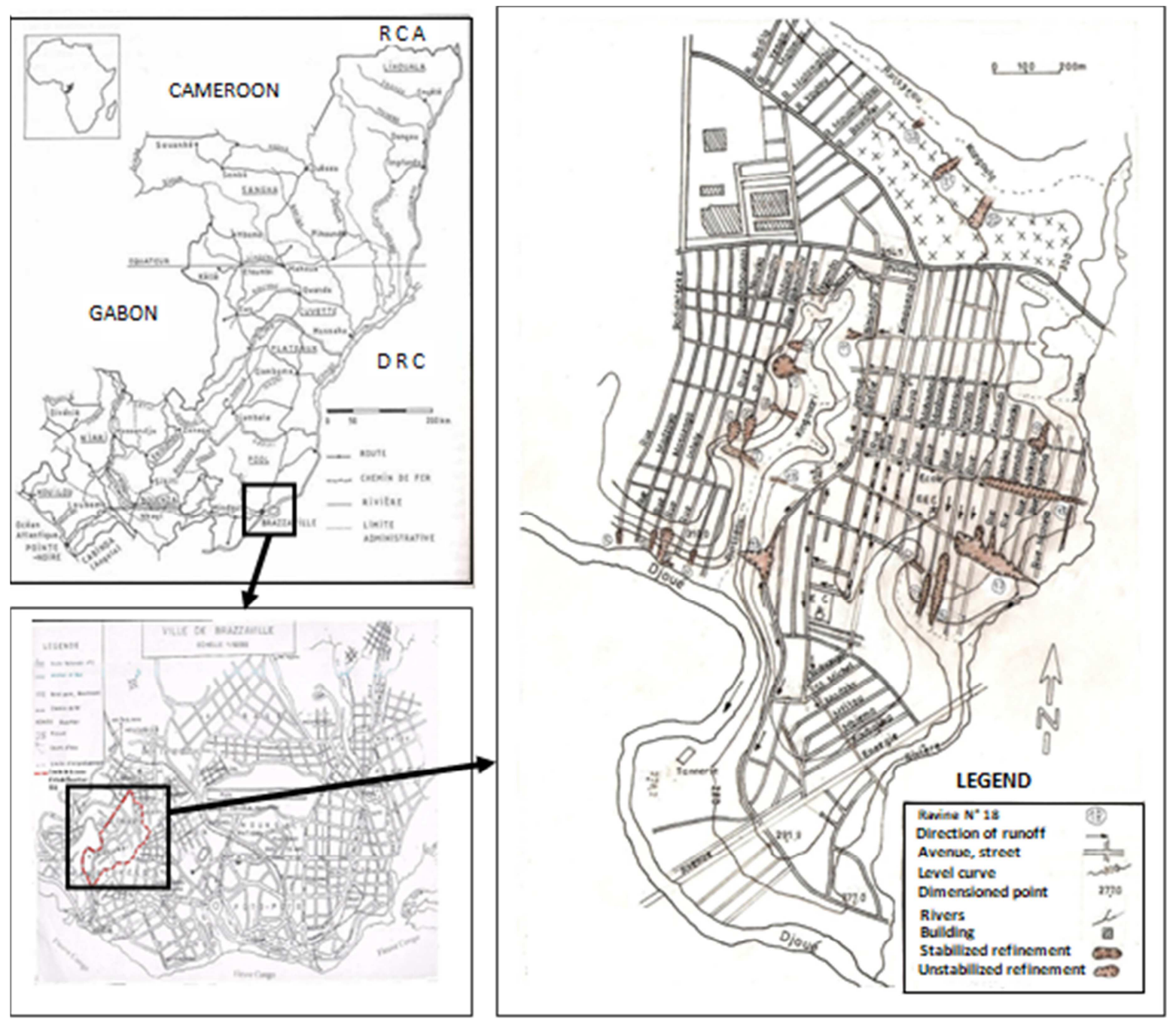

Figure 1. Location of the study area.

\section{Material and Methodology}

\subsection{Environmental Characteristics}

According to [8-11], the geological formations encountered in the city of Brazzaville are divided into three major sedimentary series, which from the base to the top, are as follows:

1) The Inkisi sandstone series, dated from the Precambrian and powerful from 6,000 to 7,000 meters, consists 
mainly of psammitic sandstones, arkosic sandstones and siliceous sandstones;

2) The sandstone series of the Stanley-Pool, dated from the Cretaceous, is unconformably based on the Inkisi sandstones; it consists of clays, compact white sandstones and soft kaolinitic sandstones;

3) The silty series of the Batéké plateaus, dated from the Tertiary, consists of polymorphic sandstones (paleogenic) covered by a thick layer of ochre sands (neogenous).

The climate of Brazzaville city is of the "Bas-Congolais" or Sudano-Guinean type, characterized by an 8-month rainy season (October to May) and a dry season from June to September [12]. The annual rainfall is about $1400 \mathrm{~mm}$ of water. The average temperature is about $25^{\circ} \mathrm{C}$ with thermal amplitudes that do not exceed $5^{\circ} \mathrm{C}$.

The soils of the city of Brazzaville are sandy or sandyclayey and generally low in organic matter [13-15].

The relief of Brazzaville consists of a series of hills, plateaus and an alluvial plain bordering the Congo River. The study area is located southwest of Brazzaville (Figure 1), in the watersheds of the Djoué and Mfilou rivers, where it occupies the left and right banks, in districts 1 (Makélékélé) and 6 (Mfilou). Its relief is that of a plateau of $314 \mathrm{~m}$ in altitude with slight slopes $(<5 \%)$ but incised over a depth of $20 \mathrm{~m}$ by the valleys of Kingouari and Kangoula, and the valleys of Mfilou and Djoué. The subsoil consists of compact clayey sandstones (Inkisi sandstone) that outcrops at the bottom of these valleys and valleys. These sandstones are topped by a weakly clayey sandy cover (Batéké silty sands), $20 \mathrm{~m}$ thick, which gives fragile and erodible soils.

The site on which the measurements were made is the Kinsoundi 16A district with an area of 250 ha and a population of 25000 inhabitants in 1996 [16]. This area is made up of the Kingouari and Latanafe districts. These are neighborhoods that were born in the 1970s and have experienced rapid and uncontrolled spatial and demographic growth. This results in the densification of habitat and the occupation of vulnerable areas such as steep slopes and valley bottoms.

Table 1. Land movements ( $t$. ha $\left.a^{-1} \cdot y r^{-1}\right)$ on the 12 main roads from 2007 to 2010 in the Kinsoundi 16 A district.

\begin{tabular}{|c|c|c|c|c|c|c|}
\hline Principal roads measured & Length (m) & Mean slope (\%) & Profilometer number & $\operatorname{Areas}\left(\mathrm{m}^{2}\right)$ & Losses / deposits $\left(\mathrm{m}^{3}\right)$ & $\begin{array}{l}\text { Losses / deposit } \\
\left(\mathrm{t} . \mathrm{ha}^{-1} \cdot \mathrm{an}^{-1}\right)^{(1)}\end{array}$ \\
\hline A. Bitsindou Av. & 614 & 2.1 & 10 & 6599 & -151.5 & -122.4 \\
\hline Kimpandzou street & 521 & 0.0 & 9 & 3124 & +27.7 & +47.4 \\
\hline Mbanzanguéri street & 428 & 0.6 & 10 & 3167 & -166.5 & -280.4 \\
\hline Ngouata street & 341 & 2.9 & 8 & 1866 & +28.1 & +80.4 \\
\hline Maténsama street & 329 & n. d. & 5 & 1834 & +18.3 & +53.1 \\
\hline Mbankoua street & 268 & 1.2 & 4 & 1652 & -21.0 & -67.7 \\
\hline Mouhounou street & 224 & n. d. & 4 & 1566 & +5.4 & +18.2 \\
\hline Salabiakou street & 165 & 0.4 & 4 & 1081 & -73.3 & -361.7 \\
\hline Mvouloungia street & 162 & 1.1 & 4 & 1506 & -9.8 & -34.7 \\
\hline Ngafoula street & 149 & n. d. & 4 & 1279 & -0.4 & -1.9 \\
\hline René Zacharie av. & 117 & 5.1 & 3 & 592 & -17.9 & -161.3 \\
\hline Mahoungou street & 93 & 2.6 & 3 & 559 & -2.8 & -27.0 \\
\hline TOTAL & 3411 & & 68 & 24825 & -363.7 & -78.1 \\
\hline
\end{tabular}

(1): the positive sign $(+)=$ filing; negative sign $(-)=$ losses; n. d. $=$ not determined.

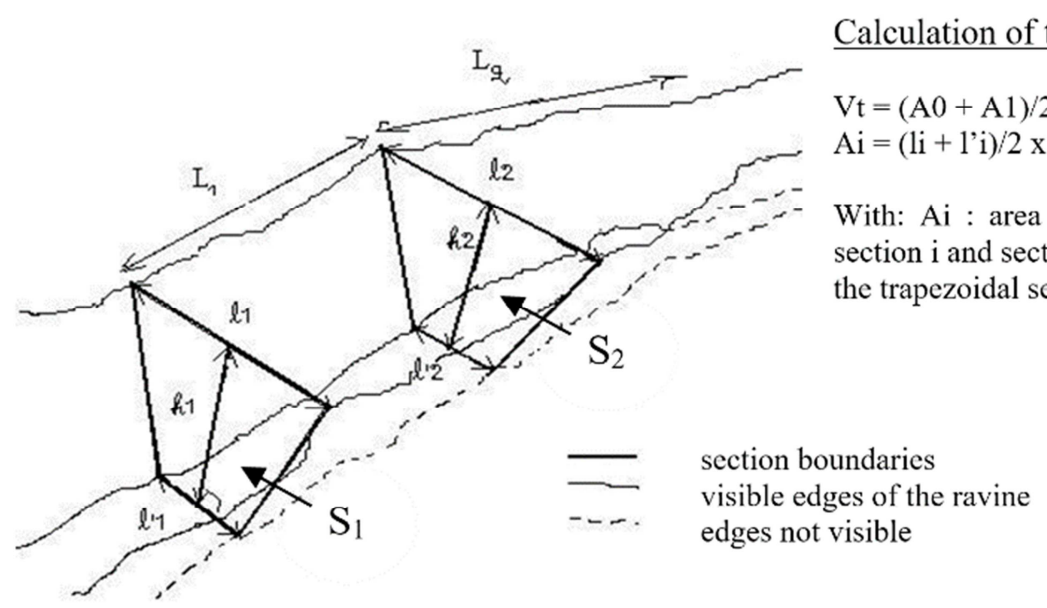

Figure 2. Diagram of a gully showing two sections (S1 and S2) separated by a distance L1. 


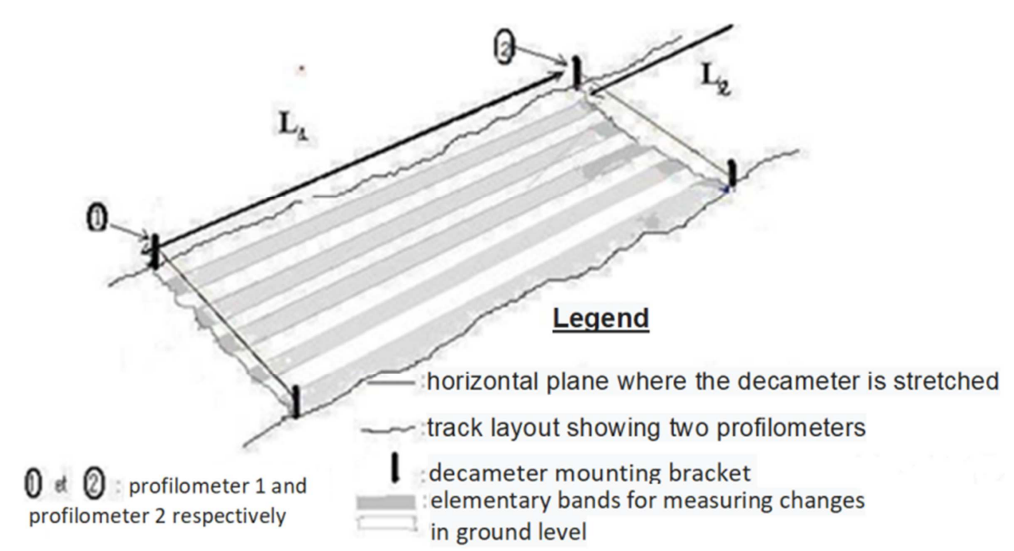

Figure 3. Layout of two profilometers on a road section subdivided into ten ground surface level measuring strips.

\subsection{Methods}

The methodology adopted to conduct this study is based on the following actions:

1) the identification and mapping of the various gully phenomena that affect neighborhoods;

2) the measurement of the slope of the land;

3) the quantification of land losses;

4) monitoring the evolution of the ground surface level;

5) characterization of stormwater flow systems in watersheds and existing equipment for controlling stormwater flows;

6) interviews with neighborhood committees and surveys of residents, in order to better understand the origin of hazards and to understand their perception of the phenomena and the work carried out to control ravines and their responses to these phenomena;

7) monitoring the evolution of a few ravines after each rainfall;

8 ) volumetric (Figure 2) and surface measurements of 12 ravines and gullies to quantify the soil losses caused by these gullies. This method consists in subdividing the ravine or gully into several simple geometric figures (rectangle, triangle, trapezoid...), which makes it possible to calculate their surfaces and volumes by the formulas indicated below;

9) measurements of changes in the surface level of road surfaces after each rainfall, to quantify soil movements (removal or accumulation) caused by runoff. These measurements were made using the profilometer method (Figure 3), which is a device for measuring the variation in the level of the surface of a ground relative to a horizontal reference level fixed on two posts placed on each side of the road [17]. For reliable measurements and regular monitoring, the width of the roadway is divided into 10 bands corresponding to 10 measurement points. On all 12 main roadways measured, 68 profilometers were installed (Table 1).

To determine the volume of soil stripped or deposited in each measuring strip, the thicknesses are first determined at each profilometer. The volume of soil moved in band $i$ is calculated by the following formula:

$$
\mathrm{V}_{\mathrm{i}}=\mathrm{L} * 1_{\mathrm{i}} *\left[\left(\mathrm{e}_{\mathrm{j}}+\mathrm{e}_{\mathrm{j}+1}\right) / 2\right]
$$

With: $\mathrm{i}=$ number of the measuring strip, from 1 to $10 ; \mathrm{L}=$ length of the section between two profilometers; $l_{i}=$ bandwidth of band $i ; e_{j}=$ thickness of soil moved in each strip at the profilometer $\mathrm{j}$.

The total volume of soil moved between two profilometers is equal to:

$$
\mathrm{Vt}=\mathrm{V}_{1}+\mathrm{V}_{2}+\mathrm{V}_{3}+\ldots+\mathrm{V}_{10}
$$

The total volume of soil displaced in the measured roadway is thus determined by the formula:

$$
\mathrm{V}=\Sigma \mathrm{Vt}(1<\mathrm{t}<\mathrm{n})
$$

The choice of the profilometer method to evaluate surface stripping erosion is justified by its simplicity, low cost, reliability and recognized representativeness, provided that the results are based on a large number of measurements [17].

\section{Results and Discussion}

Physical factors of soil erodibility in the study area

Sedimentological analyses, carried out for the technical studies of gully control works by the "Bureau de Contrôle des Bâtiments et des Travaux Publics (BCBTP)", show soil formations with a texture dominated by fine sands that are not very cohesive because they are poorly supplied with cohesion elements such as humic and clay colloids. These formations have the following characteristics: low silt + clay content $(3 \%)$, coarse sand $<20 \%$, fine to medium sand $\approx 80 \%$, plasticity and consistency index zero, in situ density 1.5 to $1.7 \mathrm{~g} / \mathrm{cm} 3$, high internal friction angle $\left(20^{\circ}\right.$ to $\left.40^{\circ}\right)$, high natural slope angle $\left(30^{\circ}\right.$ to $\left.40^{\circ}\right)$, good permeability $(300 \mathrm{~mm} / \mathrm{h})$ [7].

With regard to these values, the soil formations that cover these watersheds are erodible because they are sandy and lack cohesion and structural stability. They are therefore very sensitive to water erosion.

The analysis of rainfall chronicles gives an annual rainfall modulus of $1,383 \mathrm{~mm}$, but above all it highlights the potentially erosive nature of the rains that fall on these basins. Indeed, $33 \%$ of the rains fall with intensities above $25 \mathrm{~mm} / \mathrm{h}$ [3], the value at which the rains are considered erosive [18-20]. In addition, the analysis indicates that rains 
are frequent, raining every 2 days during the rainiest months of the rainy season: 17 days in November, 15 days in December, 13 days in March and 14 days in April (Figure 4).
During this rainy period, there is therefore a cumulative rainfall that can generate runoff, despite the good permeability of the soil formations.

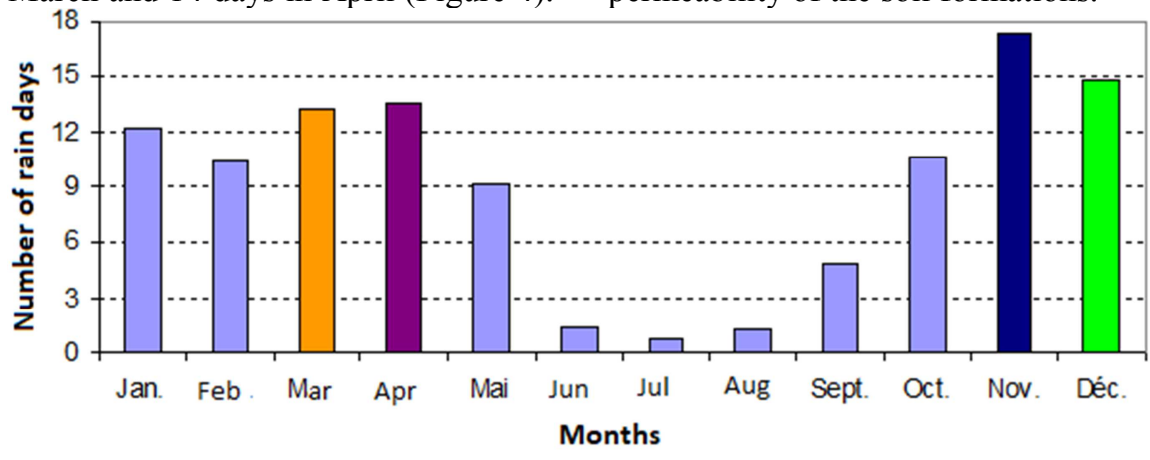

Figure 4. Average monthly rainfall frequency in Brazzaville during the period 1995-2005.
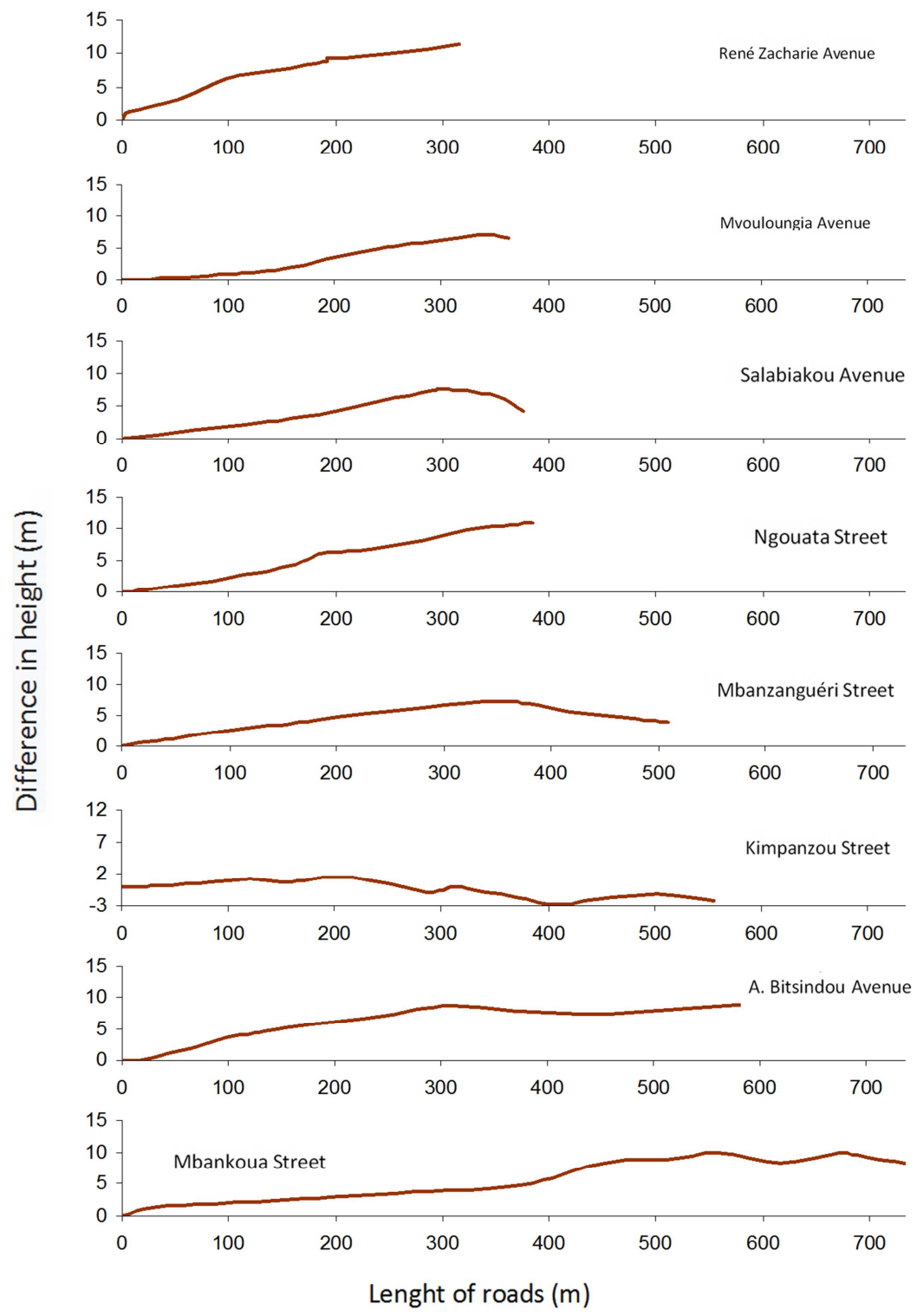

Figure 5. Topographical profiles of the main roads in Kingouari.

The distribution of slope classes shows that the main roads generally have low slopes not exceeding 5\% in absolute values (Figure 5). The average slope of the 9 main roadways measured is about $2 \%$ (Table 1 ), which is in accordance with the relatively flat topography of the plateau that constitutes the relief of these watersheds. It is on the slopes of valleys 
where the slope is steep $(>10 \%)$ that the gullies that rise on the plateau by regression are born, following a path that systematically follows the communication routes (paths, streets, avenues...) such as the Bitsindou, Bikoumou, Salabiakou, Balimalou ravines.

The length and shape of slopes also have an effect on flows on these low-slope roads as shown in Figure 5 and Table 1. Indeed, roads with low average slopes but a long length have the highest soil losses: this is the case of Avenue Alphonse Bitsindou (length: $614 \mathrm{~m}$; average slope: $2.1 \%$; losses of $122.4 \mathrm{t}^{\mathrm{ha}} \mathrm{ha}^{-1} \cdot \mathrm{yr}^{-1}$ ) and Rue Mbanzanguéri (length: $428 \mathrm{~m}$; average slope: $0.6 \%$; losses of $280.4 \mathrm{t}$. ha ${ }^{-1} \cdot \mathrm{yr}^{-1}$ ). Although shorter $(165 \mathrm{~m})$ and with a low average slope (0.4\%), Salabiakou Avenue has significant soil losses (361.7 t. ha $\left.{ }^{-1} \cdot \mathrm{yr}^{-1}\right)$ due to its convex shape upstream. The relatively high land losses (161.3 t. ha ${ }^{-1}$. $\left.\mathrm{yr}^{-1}\right)$ in Avenue René Zacharie can be explained by the average slope of $5.1 \%$. These estimated losses are very high compared to the average soil loss associated with water erosion in Brazzaville estimated at 7.86 t. ha ${ }^{-1}$. year-1 by [21]; which justifies the often catastrophic nature of erosions in these neighborhoods. But as for the Mansimou and Mayanga districts, the main ravines are located along the urban roads where circulate almost all the rainwater [22].

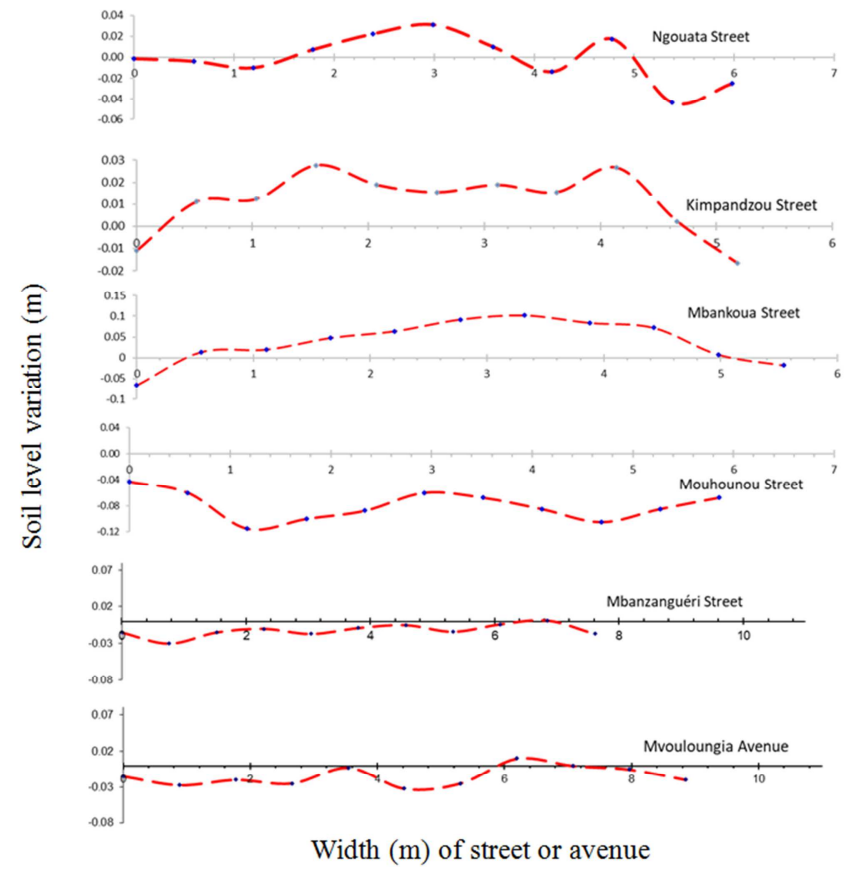

\section{Effects of the site's occupancy pattern}

Population surveys conducted in 2007 and observations in ravine neighborhoods revealed that erosions began in the 1970 s, and increased in the early 1980s with catastrophic effects in the 1990s and 2000s. These disasters, which occur mainly on unpaved and easily eroded dirt roads, are aggravated by the densification of habitat, which favours significant runoff, the lack of collectors to channel this runoff, the orientation of communications roads in the direction of the slope and their transformation into collectors of runoff water from parcels that discharge all their water into the roads due to a lack of a sanitation network. The densification of housing in the Brazzaville agglomeration was revealed by the diachronic study of satellite images [23-29].

The aggressive nature of this dynamic is explained by the combination of the following natural and anthropogenic factors: frequent rains ( $\geq 15$ days/month) very erosive with a Rusa index of 287 to 866 points, sandy soils with more than $90 \%[1,30-32]$, without cohesion and fragile, densification of the habitat on the ground ( 2 houses on average per $400 \mathrm{~m}^{2}$ plot), resulting in increased surface waterproofing and responsible for the current erosive runoff, the lack of gutters to chanalize and control runoff, resulting in roads being transformed into storm drains.

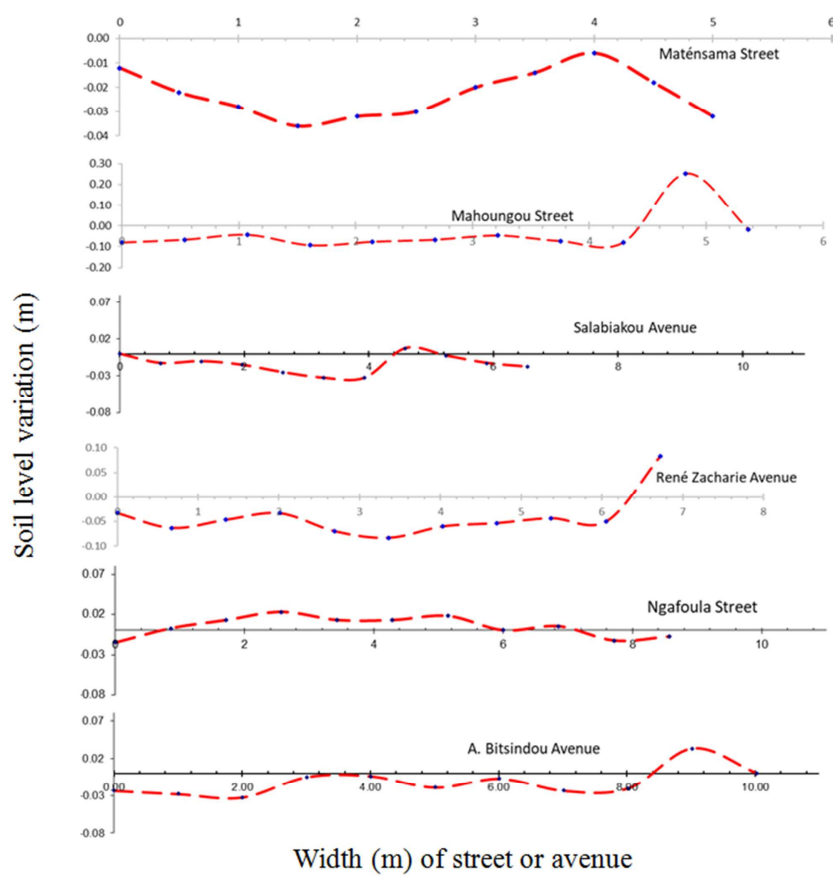

Figure 6. Average changes in soil surface estimated by profilometers in the main roads of Kingouari.

\section{Dynamics of superficial ablation}

The measurements carried out on the 12 main roads in the Kinsoundi16A district show, in 6 months of measurements, significant land losses on 9 roads whose quantities vary between 44 and 350 t. ha $^{-1}$ and inputs varying between 16 and 99 t. ha ${ }^{-1}$ on 3 roads; which gives a balance of land movements in favour of ablations amounting to $1,684 \mathrm{t}^{\mathrm{h} \mathrm{ha}^{-1}}$ (Table 1). The average profiles of the ground surface drawn up by the profilometer measurements show that for most roads the dominant trend is towards ablation, with the exception of Mouhounou, Mahoungou and Ngafoula streets, where the curves are essentially in the positive part (Figure 6).

The results obtained by the measurements of surface ablations and gullies are instructive and contribute to the understanding of the current erosive dynamics in these watersheds and beyond throughout the Brazzaville urban site. With an estimated average ablation rate of 1,684 t. ha ${ }^{-1}$, these results indicate that gullying erosion is a major problem in the Kingouari district, in the 
Mfilou-Djoué watershed. Its gravity, on the one hand, is part of the landscape through the proliferation of ravines (22 identified) and the significant number of material damages (3/4 of partially degraded roads, 52 built plots destroyed) and, on the other hand, results from the loss of human life, the victims it puts on the street and the isolation of neighborhoods, at each return from the rainy season.

\section{Gully dynamics}

The evolution of gullies is fast and spectacular when rainfall amounts are high ( $\geq \mathrm{mm}$ high). These gullies often cause damage with catastrophic aspects. In Kingouari, a 250 ha district, the equivalent of 118 plots are destroyed and 277 $152 \mathrm{~m}^{3}$ of land is removed from the roads by ravines (Table 2). Human lives were lost ( 2 children died in 2006) and 20 families, 120 people counted, became victims of the gullying erosions. This gullying dynamic, which began in the 1980s, is attributed to population densification, which allows us to establish human responsibility in this dynamic in accordance with [22] in the neighbouring districts of Mansimou and Mayanga.

Table 2. Estimated land losses from the Kintsoundi $16 \mathrm{~A}$ ravines.

\begin{tabular}{|c|c|c|c|c|c|c|}
\hline $\mathbf{N}^{\circ}$ & Gullying & Length (m) & Area destroyed (ha) & Average depth (m) & Losses $\left(\mathrm{m}^{3}\right)$ & Losses (t. ha $\left.{ }^{-1}\right)^{*}$ \\
\hline 1 & Badiantséké gully & 42.00 & 0.0252 & 1.00 & 126 & 8000 \\
\hline 2 & Massengo gully & 77.00 & 0.0578 & 4.52 & 1964 & 54333 \\
\hline 3 & Intali gully & 91.05 & 0.1745 & 8.77 & 9992 & 91596 \\
\hline 5 & Nkouka gully & 169.27 & 0.2047 & 4.95 & 8753 & 68382 \\
\hline 5 & Balimalou 2 gully & 51.45 & 0.1189 & 9.65 & 7406 & 99653 \\
\hline 7 & Paul Ndouna gully & 74.65 & 0.1586 & 10.38 & 10282 & 103693 \\
\hline 9 & Bikoumou (stabilized) gully & 91.30 & 0.2809 & 9.00 & 20145 & 114711 \\
\hline 10 & Bikoumou (no stabilized) gully stabilized & 66.20 & 0.1621 & 7.13 & 9115 & 89979 \\
\hline 11 & Malonga gully & 59.10 & 0.0975 & 6.46 & 4240 & 69534 \\
\hline 12 & Bitsindou bis gully & 46.00 & 0.0239 & 2.53 & 396 & 26437 \\
\hline 13 & Bitsindou (stabilized) gully & 258.70 & 0.5108 & 6.01 & 36271 & 113603 \\
\hline 14 & Mantsanga gully & 90.20 & 0.0883 & 4.49 & 2947 & 53378 \\
\hline 15 & Matensama gully & 135.00 & 0.2180 & 9.96 & 14353 & 105330 \\
\hline 16 & Ngouata gully & 204.88 & 0.4103 & 6.61 & 23967 & 93446 \\
\hline 18 & Mvouloungia gully & 288.20 & 0.7241 & 7.85 & 39596 & 87488 \\
\hline 19 & René Zacharie gully & 162.80 & 0.1948 & 7.05 & 8680 & 71277 \\
\hline 20 & Ntsouelé (Cemetery) gully & 46.50 & 0.1256 & 4.13 & 3863 & 49211 \\
\hline 21 & Kibossi (Cemetery) & 45.60 & 0.0603 & 4.26 & 1558 & 41314 \\
\hline 22 & Samba cher (Cemetery) & 16.00 & 0.0048 & 2.70 & 92 & 30600 \\
\hline Total & & 2555 & 4.7051 & 6.00 & 277152 & 94230 \\
\hline
\end{tabular}

${ }^{(*)}$ mean of soil density: $1.6 \mathrm{~g} . \mathrm{cm}^{-3}$.

In addition, the analysis of Table 2 makes it possible to estimate the density of ravines in the district at $10.22 \mathrm{~m} . \mathrm{ha}^{-1}$. Based on the ravine erosion severity scale of 6 classes, the erosion in Kingouari corresponds to class 4 and can be considered severe [32-34].

\section{Means of combating gullying}

The means of control used fall into two main categories: those used by the population and those used by the public authorities to try to control gullies.

The ravine and gully control techniques put in place by the population are mainly based on sack dams filled with soil. Indeed, $87 \%$ of the people surveyed use this technique of bags filled with soil (Table 3), placed across the ravine, to prevent runoff, by spreading liquid and solid flows. People recognize that this technique gives some results when applied to small gullies, but it is not very effective at ravines and gullies of a certain size.

The soil bag technique, although not very effective because of its very short life span, $<3$ to 4 months, has significantly contributed to delaying the evolution of gullies and avoiding the transformation of neighborhood soils into unbuildable land [1]. In combination with other biological techniques and better supervision and training of the inhabitants, the soil bag technique would probably be more effective.

In an attempt to control major gullies, $4 \%$ of the population dump solid waste at the head of the gullies which, when dense, temporarily slows down the evolution of the gullies. Vegetation techniques (with bamboos or grass) are poorly practiced $(2.5 \%$ of the people surveyed) despite the good resistance of these plants and their proven effectiveness. Plants such as vetiver are cultivated sporadically at the edge of the plots. Soil tire techniques and concrete dikes are hardly used ( $1 \%$ of the population surveyed) because of the costs involved for poor populations $[1,5]$.

The public authorities achievements are based on the gabion technique. This very expensive technique is only effective when it is well designed and constructed. The development of a few ravines, using this technique, by the companies Conca-Congo in 1982 and "Congolaise Générale Industrielle (CGI)", which treated 3 ravines (1.7ha out of 4.7ha of destroyed areas) on behalf of the Emergency Project for the Rehabilitation of Infrastructures and Improvement of Living Conditions of Populations (PURICV) in 2006, made it possible to stabilize these ravines and save many homes (52 by the work carried out on the 3 ravines by the CGI).

The populations of the Kinsoundi 16A district consider 
that the gully control work carried out by the public authorities is insufficient to stop the manifestations of water erosion in their district, which is still under serious threat from gully erosion. Indeed, only $32 \%$ of the populations are satisfied with this work (Table 4).

Despite this feeling, the work has given new hope to the neighbourhood as the treatment of the ravines has been accompanied by new constructions around the 3 ravines, while despair has pushed the inhabitants of some threatened houses to leave.

Table 3. Population actions to control erosion in Kinsoundi $16 \mathrm{~A}$.

\begin{tabular}{llll}
\hline $\mathbf{N}^{\circ}$ & Actions to combat erosion & Number & $\%$ \\
\hline 1. & Bags filled with soil & 239 & 86.9 \\
2. & Dumping of household waste & 12 & 4.4 \\
3. & Lawn and bamboo plantations & 7 & 2.5 \\
4. & Concrete dikes & 3 & 1.1 \\
5. & No answer & 14 & 5.1 \\
TOTAL & & 275 & 100.0 \\
\hline
\end{tabular}

Table 4. Assessment of the work carried out in the Kingouari district.

\begin{tabular}{llll}
\hline $\mathbf{N}^{\circ}$ & Assessment of the work carried out & Number & $\mathbf{\%}$ \\
\hline 1. & Insufficient & 185 & 67.3 \\
2. & Satisfactory & 87 & 31.6 \\
3. & No opinion & 3 & 1.1 \\
TOTAL & 275 & 100.0 \\
\hline
\end{tabular}

\section{Conclusion}

The Kinsoundi 16A district, characterized by fragile ground and hilly terrain, is vulnerable to gullies like the other districts of the city of Brazzaville located on plateaus. The results obtained with this study show that the erodibility of the soils in this area is linked to runoff that generates significant material transport causing regressive erosions, the manifestations of which are often catastrophic. With generally low slopes $(<5 \%)$, erosive phenomena are favoured on roads that are often long and marked out according to the direction of the slope. We are thus witnessing continuous removal of roads and gullies at the bottom of slopes that gully up along these arteries.

The balance shows a soil loss of 94,247 t. ha ${ }^{-1}$ over the period observed, which was favoured by the combination of natural and anthropogenic factors represented by very eroding rains, sandy soils with more than $90 \%$ of the soil lacking cohesion and fragile, and the densification of the habitat. This led to an erosion of severity 4 and catastrophic manifestation.

The technics of control used by the populations are inadequate and ineffective to treat the catastrophic gullies that occur in the district. It is therefore imperative that, in addition to a few attempts to control ravines that have so far been ineffective in preventing the proliferation of ravines each time the rainy season returns, because they are essentially curative and punctual, a policy to prevent erosion risks must be put in place. This must take into account all the catchment areas on which the ravine districts are located, which must be treated as risk basins.

The results obtained by the measurements of surface ablations and gullies are instructive and contribute to the understanding of the current erosive dynamics in these watersheds and beyond throughout the Brazzaville urban site. These results indicate that gullying erosion is a major problem in the Kinsoundi districts of the Mfilou-Djoué watershed. Its gravity, on the one hand, is part of the landscape through the proliferation of ravines (22 identified) and the significant number of material damages (3/4 of partially degraded roads, 52 built plots destroyed) and, on the other hand, results from the loss of human life, the victims it puts on the street and the isolation of neighbourhoods, at each return from the rainy season.

The estimation of erosive dynamics made in this study deserves to be refined in order to highlight them. For gullies, it would be interesting to determine their density and annual rate of change over a given period of time, in order to understand the impact of certain parameters such as antierosion developments and the increase in impermeable surfaces on their development. Surface removal requires regular measurements over a fairly long period of time to better estimate annual land losses. This first attempt to quantify water erosion should be extended to the entire urban area of Brazzaville.

\section{References}

[1] Louembé D., Nzila J. D., 2007. Impact assessment studies for the development of eroded areas and for the construction and rehabilitation of paved roads and tertiary drainage network in Brazzaville. PURICV-IDA, Brazzaville, 96 p. + annexes.

[2] Louembé D., 1978. The modalities of erosion on the urban site of Brazzaville. T. E. R. of tropical geomorphology, UMNG, Brazzaville, 115 p.+annexes.

[3] Louembé D., Tchicaya J. A., 1993. The problems of degradation of urban sites by water erosion in southern Congo. PNAE-Congo, Brazzaville, $114 \mathrm{p}$.

[4] Ngabaka-Koubango A., 2004. Current erosion dynamics in a watershed of the Mfilou River in Massina (Brazzaville, Congo). CAICEG Memory, Marien Ngouabi University, Brazzaville, 59 p. + Annexes.

[5] Mboungou-Nsompi P., 2006. Manifestation of water erosion and methods of control in the districts of Brazzaville: case of the watersheds of Kinsoundi, M'filou-Kingouari and MbimiMassina. CAICEG Memory, Marien Ngouabi University, Brazzaville, $78 \mathrm{p}$.

[6] Kaya-Mabiala D., 2007. Current dynamics of water erosion in the Kingouari, Mfilou and Djoué watersheds (district 16A Kinsoundi-Brazzaville). CAPES Memory, Marien Ngouabi University, Brazzaville, 65p + Annexes.

[7] Mayima A. B., 2007. Study of erosion in the Kingouari, Kinsoundi, Météo, Ngangouoni and Moukoundzi-Ngouaka districts in the Djoué watershed south of Brazzaville. Master's thesis in physical geography, Marien Ngouabi University, Brazzaville, $118 \mathrm{p}$.

[8] Cosson J., 1955. Explicative notice on the Pointe-Noire and Brazzaville maps. General Government of French Equatorial Africa, Paris, $56 \mathrm{p}$. 
[9] Alvarez Ph., Marin J-C. et Vicat J-P., 1995. The formation of the Inkisi (West Congolese Supergroup) in Central Africa (Congo and Bas-Zaire): a Paleozoic age delta filling an expanding basin. Journal of Earth Sciences, 20 (2), 119-131.

[10] Le Marechal A., 1966. Contribution to the study of the Plateaux Batéké. Geology, Geomorphology, Hydrogeology. ORSTOM Brazzaville, 24 p.

[11] Dadet P., 1969. Explicative notice for the geological map of the Republic of Congo-Brazzaville at 1/500000 (zone between parallels 2 and $5^{\circ}$ South). BRGM memory $\mathrm{N}^{\circ} 70$, Paris, $103 \mathrm{p}$.

[12] Samba-Kimbata M. J., 1978. The climate of Bas-Congo. Doctoral thesis, University of Dijon, France, 280 p.

[13] Denis B., 1974: Explicative notice $\mathrm{n}^{\circ}$ 52. Soil map Brazzaville -Kinkala, People's Republic of Congo at 1/200,000. ORSTOM, Paris, 101 p.

[14] Schwartz D., 1987. Soils around Brazzaville and their use. ORSTOM, Pointe-Noire, $21 \mathrm{p}$.

[15] Mietton M., Cordier S., Frechen M., Dubar M., Beiner M., Andrianaivoarivony R., 2014. New insights into the age and formation of the Ankarokaroka lavak and its associated sandy cover (NW Madagascar, Ankarafantsika natural reserve). Earth Surface Processes Landforms, 39, 1467-1477.

[16] CNSEE, 1996. Population estimates for the Republic of Congo. Unpublished document. CNSEE, Brazzaville, $343 \mathrm{p}$.

[17] Feret J. B., Sarrailh J. M., 2005. Use of a simple and accurate measuring device for the study of erosion in Mayotte. Woods and forests in the tropics, 286, 29-40.

[18] Roose E., 1980. Some conclusions of French research on current soil dynamics in West Africa. ORSTOM Papers, Pedological Serie, XVIII (3-4), 285-296.

[19] Roose E., 1981. Current Dynamics of Tropical Ferrallitic and Ferruginous Soils in West Africa. ORSTOM, Paris, 570 p.

[20] Mesrar H., Sadiki A., Navas A., Faleh A., Quijan L., Chaaouan J., 2014. Water erosion modeling and causal factor studies. Case of wadi Sahla, Morocco. Proceedings of the Symposium on the National Water Information System. 02-04 décember 2014, 7-15.

[21] Kémpéna A., Guardado R. L., Bilembi D., 2016. Estimating Soil Loss by Water Erosion in the Microwatersheds of Brazzaville City. International Journal of Science and Research (IJSR), 5 (12), 1623-1626.

[22] Kombo-Kissangou R. J., Sitou L., M'bouka Milandou I., 2018. Dynamics of water erosion in the Mansimou and Mayanga neighborhoods south of Brazzaville (Congo): analysis of soil permeability and texture, cubage and mapping of gullies. Moroccan Journal of Geomorphology, 2, 36-54.

[23] Kémpéna A., Boudzoumou F., Nganga D. and Ray H., 2014. Cartography of environmental vulnerability to soil erosion of the urban area of Brazzaville using Geographic Information System (GIS). Int. Res. J. Environment Sci., 3 (5), 35-43.

[24] Jaoued M., Gueddari M., Saadaoui M., 2005. Modelling of water erosion in the watershed of the wadi M'Khachbia (North-West Tunisia). Geo-Eco-Trop, 29, 15-24.

[25] Zouagui A., Sabir M., Naimi M., Chikhaoui M., Benmansour M., 2018. Modelling the risk of water erosion using the universal equation of land loss in the Western Rif: case of the Moulay Bouchta watershed (Morocco). European Scientific Journal, 14 (3), 524-544.

[26] Markhi A., Laftouhi N. E., Soulaimani A., Fniguire F., 2015. Quantification and evaluation of water erosion using the Rusle model and deposition integrated in a GIS. Application in the N'Fis watershed in the High Atlas of Marrakech (Morocco). European Scientific Journal, 11 (29), 340-356.

[27] Sadiki A., Faleh A., Zêrere J. L., Mastass H., 2009. Quantification of sheet erosion in the Sahla Wadi watershed. Geographic Papers, 6, 59-70.

[28] Yjjou M., Bouabid R., El Hmaidi A., Essahlaoui A., El Abassi M., 2014. Modelling of water erosion using GIS and the universal soil loss equation at the level of the Oum Er-Rbia catchment area. The International Journal of Engineering and Sciences, 3 (8), 83-91.

[29] Meliho M., Khattabi A., Mhammdi N., Hongming Z., 2016. Water erosion risk mapping using the revised universal equation of soil loss, remote sensing and GIS in the Ourika watershed (High Atlas, Morocco). European Scientific Journal, 12 (32), 277-297.

[30] Kémpéna A., Bilembi D., Boudzoumou F., \& Nganga D., 2014. Methodology for erosion risk zoning in the city of Brazzaville study of case in the urban area. ARPN Journal of Earth Sciences, 3 (1), 9-16.

[31] Van Caillie X. D., 1989. Erodability of sandy soils in Zaire and erosion control. ORSTOM Papers, Pedological serie, XXV (1-2), 197-208.

[32] Plamondon A. P., 2009. Integrated management plan for the Mateo and Las Aguas watersheds in Haiti and Comendor, Alonso, Caña and Las Lagunas in the Dominican Republic. Binational project for the rehabilitation of the Artibonite River watershed in the border area between Haiti and the Dominican Republic (Project No. 4456/A-031937). Consortium OxfamQuébec / CRCR Sogema, 123 p.

[33] Plamondon A. P., 2010. Hydrology, erosion and watershed management in the tropical rainforest biome. Course manual. Faculty of Forestry, Geography and Geomatics. Laval University, Quebec, Canada. 717 p.

[34] Nzoussi H. K., Feng L. J., 2014. Management of the urban environment in Brazzaville: problems and perspectives. European Scientific Journal, 10 (29), 209-216. 